Tarbawy : Jurnal Pendidikan Islam

ISSN : 2407-4462 (Cetak), 2614-5812 (Elektronik)

Vol. 7, No. 1, 2020, Hal. 23-32

DOI: https://doi.org/10.32923/tarbawy.v7i1.1184

\title{
Intervensi Latihan Sensori Motorik Dalam Pengembangan Kinestetik Anak Autis
}

\author{
Zonalisa Fhatri ${ }^{1}$ \\ ${ }^{1}$ IAIN Syaikh Abdurrahman Siddik Bangka Belitung
}

Info Artikel :

Diterima 4 April 2020

Direvisi 21 April 2020

Dipublikasikan 27 April 2020

\section{Kata Kunci:}

Intervensi

Latihan Sensori-Motorik

Anak Autis

\section{Keywords: \\ Intervention \\ Sensory-motor Exercise \\ Autistic Children}

\begin{abstract}
ABSTRAK
Penelitian ini bertujuan untuk mengetahui intervensi latihan sensori motorik dalam pengembangan kinestetik anak autis di Pusat Layanan Autis (PLA) Provinsi Kepulauan Bangka Belitung.

Penelitian ini merupakan penelitian lapangan (field research) berdasarkan sumber datanya. Metode yang digunakan adalah penelitian kualitatif yang dianalisis secara deskriptif. Jumlah subjek dalam penelitian ini sebanyak 5 anak. Responden diambil berdasarkan purposive sampling. Adapun teknik pengumpulan data menggunakan metode wawancara, observasi, dan dokumentasi. Sedangkan datanya dianalisis menggunakan reduksi data, penyajian data, dan penarikan kesimpulan. Hasil penelitian ini menunjukkan bahwa latihan sensori integrasi (SI) mencakup 7 bidang yaitu, vestibular, taktil, propioseptif, visual, auditori, gustatori, dan olfaktori. Latihan pengembangannya disesuaikan dengan kondisi dan karakteristik anak, karena antara anak yang satu dan anak lainnya berbeda. Perkembangan latihan sensori motorik dari kelima subjek mempunyai karakteristik kemampuan yang berbeda-beda. Kemajuan atau kecepatan dalam merespons stimulasi latihan mereka dipengaruhi oleh usia, stimulasi dari luar, serta kegiatan stimulasi oleh orangua di rumah.

Kontribusi keilmuan dalam penelitian ini adalah dengan bertambahnya pengetahuan/informasi baru di lapangan, maka latihan sensori motorik bisa diterapkan di PAUD inklusif dengan media yang bisa dimodifikasi untuk anak autisme.
\end{abstract}

\section{ABSTRACT}

This study aims to determine motor training intervention in the kinesthetic development of autistic children in the Autism Service Center of the Province of Bangka Belitung Islands. Based on the data source, this research is a field research using qualitative research methods that is analyzed descriptively. The number of subjects in this study is 5 children. Respondents were taken based on purposive sampling. The data collection techniques used interviews, observation, and documentation and the data was analyzed using data reduction, data presentation, and conclusion. The results of this study indicated that the sensory integration (SI) exercise includes 7 areas namely, vestibular, tactile, propioceptive, visual, auditory, gustatory, and olfactory. Exercise development was tailored to the conditions and characteristics of children, because between one child and another child was different. The progress of motor sensory training had five subjects and all of which had different characteristics of ability. The progress or speed in responding to their exercise stimulation was affected by age, environmental stimulation, and home-based exercise.

Scientific contribution of this research is with addition of new knowledge/information in the field and motor sensory training can be applied in inclusive PAUD with modifiable media for autistic children.

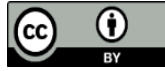

This is an open access article distributed under the Creative Commons Attribution License, which permits unrestricted use, distribution, and reproduction in any medium, provided the origin work is properly cited. (O2019 by author.

\section{Koresponden:}

Zonalisa Fhatri

Email: zonalisa@gmail.com

\section{Pendahuluan}

Pendidikan anak usia dini memiliki fungsi utama mengembangkan semua aspek perkembangan anak, meliputi perkembangan kognitif, bahasa, fisik motorik, sosial, emosional, bahkan musik. PAUD berfungsi membina, menumbuhkan, dan mengembangkan seluruh potensi anak usia dini secara optimal sehingga 
terbentuk perilaku dan kemampuan dasar sesuai dengan tahap perkembangannya agar memiliki kesiapan untuk memasuki pendidikan selanjutnya (Musbikin, 2010).

Jika anak usia dini adalah fondasi masa depan Indonesia, maka segala perkembangan anak di masa ini sangat penting untuk diperhatikan tidak terkecuali juga bagi anak luar biasa atau berkebutuhan khusus (ABK). Menurut Heward anak berkebutuhan khusus adalah anak dengan karakteristik khusus yang berbeda dengan anak pada umumnya tanpa selalu menunjukkan pada ketidakmampuan mental, emosi atau fisik.

Adapun menurut (Peraturan Pemerintah, 2010) Pasal 129 ayat (3) menetapkan bahwa, peserta didik berkelainan terdiri atas peserta didik yang tunanetra, tunarungu, tunawicara, tunagrahita, tunadaksa, tunalaras, berkesulitan belajar, lamban belajar, autis, memiliki gangguan motorik, menjadi korban penyalahgunaan narkotika, obat terlarang dan zat adiktif, serta memiliki kelainan lainnya. Namun, anak disabilitas yang seharusnya mendapatkan hak pendidikan yang sama justru banyak mendapat penolakan di sekolah-sekolah.

Padahal berdasarkan (Kementerian Pendidikan Nasional, 2003) tentang Sistem Pendidikan Nasional Bab 1, Pasal 1, Butir 14 bahwa:

"Pendidikan anak usia dini adalah suatu upaya pembinaan yang ditujukan kepada anak sejak lahir sampai dengan usia enam tahun yang dilakukan melalui pemberian rangsangan pendidikan untuk membantu pertumbuhan dan perkembangan jasmani dan rohani agar anak memiliki kesiapan dalam memasuki pendidikan lebih lanjut.

Oleh karena itu, sebagaimana anak disabilitas lainnya maka anak autis memiliki hak untuk memperoleh layanan pendidikan khusus, yang bisa diselenggarakan pada satuan pendidikan reguler atau inklusif maupun dalam satuan pendidikan khusus. Hal ini merujuk pada Permendiknas No. 70 tahun 2009 ayat 1 dan 2 dinyatakan bahwa:

"(1) Tujuan penyelenggaraan pendidikan inklusif adalah memberikan kesempatan yang seluas-luasnya kepada semua peserta didik dari berbagai kondisi dan latar belakang untuk memperoleh pendidikan yang bermutu sesuai dengan kebutuhan dan kemampuannya. Dilanjutkan dalam ayat (2) dinyatakan bahwa pendidikan inklusif bertujuan menciptakan sistem pendidikan yang menghargai keanekaragaman, dan tidak diskriminatif bagi semua peserta didik".

Anak Autis merupakan bagian integral dari anak luar biasa. Anak Autistik ialah anak yang mengalami gangguan perkembangan yang kompleks antara lain mempengaruhi cara seseorang untuk berkomunikasi dan berinteraksi sosial dengan orang lain. Autis berasal dari kata bahasa Yunani yaitu autos yang artinya sendiri, yang merupakan suatu istilah yang mencirikan bahwa seseorang menarik diri (withdrawl) dari interaksi sosial dengan lingkungannya sehingga mereka seolah-olah hidup di dunianya sendiri.

Istilah autis digunakan pertama kali oleh Leo Kanner pada tahun 1943. Penyebab autisme salah satunya adalah ketidakberfungsian sistem saraf di otak, selain menimbulkan masalah dalam belajar dan bahasa, anak autistik mempunyai masalah dalam mengembangkan kemampuan untuk memproses infomasi yang diterima melalui alat indera. Adapun ciri-ciri anak autis tersebut, yaitu: gangguan dalam bidang komunikasi verbal maupun non-verbal, gangguan dalam bidang interaksi sosial, gangguan dalam bidang perilaku, gangguan dalam bidang perasaan atau emosi, serta gangguan dalam persepsi sensorik (Mudjito et al., 2014).

Berdasarkan data yang dikeluarkan oleh Badan Pusat Statistik, jumlah autisme di Indonesia pada tahun 2010 diperkirakan mencapai 2,4 juta orang. Pada tahun tersebut jumlah penduduk Indonesia sebanyak 237,5 juta orang dengan laju pertumbuhan 1,14 persen. Jumlah penderita autisme di Indonesia diperkirakan mengalami penambahan sekitar 500 orang setiap tahunnya (Mudjito et al., 2014).

Selanjutnya berdasarkan data dari pusat layanan autis (PLA) Bangka Belitung, menunjukkan jumlah anak autis mengalami peningkatan dan ini terlihat dari memasuki satu tahun pusat layanan autis ini berdiri. Pada tahun 2015 jumlah anak autis berjumlah 22 orang. Memasuki 2016 jumlah anak autis mengalami peningkatan menjadi 27 anak. Dari 22 anak di tahun 2015 lalu, 15 diantaranya masih menjalankan terapi di tahun 2016, sehingga total anak yang ditangani PLA hingga saat ini adalah sebanyak 42 anak.

Melalui data di atas semakin jelas bahwa jumlah anak autisme semakin meningkat, perlu adanya upaya yang dilakukan. Saat ini upaya yang dilakukan pemerintah adalah memperluas kesempatan dan akses pendidikan, juga membangun pusat terapi autisme di sejumlah kota di Indonesia sehingga diharapkan sebelum masuk bangku sekolah anak autis sudah memiliki kecakapan khusus yang meliputi kecakapan bergaul, berkomunikasi, maupun bersosialisasi yang sesuai dengan tahap perkembangannya.

Perkembangan meliputi seluruh aspek yakni perkembangan bahasa, sosial, emosional, serta perkembangan fisik motorik anak. Namun sering kali para profesionalpun hanya memfokuskan pada masalah-masalah emosi, sosial, dan keluarga. Padahal perkembangan motorik juga menjadi bagian yang tidak terpisahkan dalam kehidupan anak autistik (Ahmad Susanto, 2011).

Kemampuan motorik adalah kemampuan dalam mengkoordinasikan gerakan tubuh. Ada dua macam kemampuan ini, yaitu motorik kasar dan motorik halus. kemampuan motorik halus pada anak usia dini 
adalah beraktivitas dengan menggunakan otot halus seperti menulis, meremas, menggenggam, menggambar, menyusun balok dan memasukkan kelereng ke dalam lubang, sedangkan motorik kasar anak adalah kemampuan menggerakkan berbagai bagian tubuh seperti berjalan, melompat, berlari, melempar, menangkap, menendang, dan bermain sepeda (Abdurrahman, 2012).

Berkaitan dengan ini, salah satu cara untuk membantu perkembangan syaraf gerak anak autis adalah program latihan sensori motorik yang tujuannya untuk merangsang proses sensori dari anak autis sehingga dia lebih adaptif terhadap lingkungan. Latihan sensorimotor ini lebih menekankan pada pengembangan propioceptive (posisi tubuh), tactile (peraba), dan vestibular (keseimbangan) sebagai dasar untuk pengembangan motorik halus (fine motor) dan motorik kasarnya (groos motor), (Picauly, 2016).

Stimulus yang ditujukan pada pancaindra anak akan direspons secara motorik sehingga orang lain dapat memahami maksud melalui bahasa tubuh anak. Dengan dasar pemahaman ini, metode sensori motorik dapat membantu anak yang mengalami gangguan perkembangan. Metode sensori motorik merupakan pelatihan yang mengajak anak untuk mau mencoba sendiri. Dari mencoba sendiri, anak bisa lebih memahami apa yang sedang dicobanya, bisa memperbaiki sesuatu jika ia anggap salah, juga bisa berkreasi dengan lebih baik lagi. Metode ini termasuk dengan bagaimana para terapis dan guru ikut mengasah persepsi visual dan auditori anak, sehingga anak mampu mengekspresikan apa yang dipikirkan dan dirasakannya.

Adapun penelitian sebelumnya yang relevan dengan penelitian ini, diantaranya: Pertama, penelitian oleh (Resmisari, 2016), yang berjudul "Penerapan Metode ABA (Applied Behavior Analysis) untuk Meningkatkan Kontak Mata pada Anak dengan Gangguan Autis: Sebuah Laporan Kasus". Pemberian intervensi ABA dilakukan dengan pertimbangan karena metode ini diketahui efektif dalam mengubah perilaku pada anak dengan gangguan autis. Metode ABA ini menggunakan prinsip-prinsip dasar pengkondisian operan yaitu dengan pemberian reinforcement positif. Intervensi yang telah dilakukan pada subjek menunjukkan hasil bahwa kontak mata subjek meningkat dari dua detik menjadi tiga detik.

Kedua, jurnal penelitian oleh (Marienzi, 2012), "Meningkatkan Kemampuan Mengenal Konsep Angka Melalui Metode Multisensori bagi Anak Autis". Hasil penelitian ini menyimpulkan bahwa, setelah diberikan intervensi pada anak autis x yang belum mengenal konsep angka dapat meningkat. Di awal penelitian atau pada kondisi baseline anak belum mampu mengenal konsep angka dengan benar, namun setelah diberikan intervensi dengan menggunakan metode multisensori anak dapat mengenal konsep angka dengan baik dan benar. Dengan persentase perbandingan $46.25 \%$ pada kondisi A dan $95 \%$ pada kondisi B.

Ketiga, jurnal penelitian oleh (Prasetyoningsih, 2016), yang berjudul "Pengembangan Tindak Bahasa Terapi dalam Intervensi Anak Autis Spektrum Perilaku". Simpulan hasil penelitian adalah produk prototipe tindak bahasa terapi dalam intervensi anak autis spektrum perilaku telah memenuhi syarat keberterimaan yang dapat digunakan sebagai referensi untuk menangani anak autis gangguan perilaku.

Perbedaan penelitian ini dengan penelitian sebelumnya adalah terletak pada intervensi, metode dan aspek yang dikembangkan, serta lokasi penelitiannya. Disini peneliti fokus terhadap pengembangan aspek kinestetik anak autisme dengan penerapan latihan sensori-motorik (Sensory-integration) di Pusat Layanan Autis (PLA) Provinsi Kepulauan Bangka Belitung. Selanjutnya ada tiga rumusan masalah dalam penelitian ini, antara lain:

1. Bagaimana implementasi latihan sensori motorik dalam pengembangan kinestetik anak autis di Pusat Layanan Autis (PLA) Provinsi Kepulauan Bangka Belitung?

2. Bagaimana kemampuan kinestetik anak autis di Pusat Layanan Autis (PLA) Provinsi Kepulauan Bangka Belitung?

3. Adakah faktor penghambat dan pendukung latihan sensori motorik dalam pengembangan kinestetik anak autis di Pusat Layanan Autis (PLA) Provinsi Kepulauan Bangka Belitung?

\section{Kerangka Teoritik}

\section{Latihan Sensori Motorik}

Sensori motorik merupakan kemampuan untuk mengolah dan mengartikan seluruh rangsangan sensori yang diterima dari tubuh maupun lingkungan dan kemudian menghasilkan respons yang terarah. Gejalanya bisa tampak dari pengendalian sikap tubuh, motorik halus dan motorik kasar. Adanya gangguan dalam keterampilan persepsi, kognitif, psikososial dan mengolah rangsangan (Picauly, 2016).Gangguan integrasi sensorik (sensory integration disorder) sangat umum terjadi pada anak-anak autis.

Anak yang menderita autis tidak dapat mengintegrasikan informasi sensorik yang diterima tubuh untuk dikirim ke otak, seperti sentuhan, penciuman, penglihatan, rasa, dan pendengaran. Karenanya, anak autis sulit merespon lingkungan mereka dengan tepat. Sensori integrasi adalah bagaimana seseorang mengatur informasi yang diperoleh dari lingkungan di sekitarnya sehingga informasi tersebut dapat digunakan sesuai dengan situasi, yang termasuk kategori sensori adalah panca indra (mata, hidung, telinga, kulit, lidah) 
ditambah dengan 2 sistem sensorik lain, yaitu vestibular (berkaitan dengan gaya gravitasi bumi, keseimbangan) dan proprioseptif (kerja otot dan sendi).

Dengan adanya latihan sensori motorik diharapkan dapat meningkatkan kemampuan beratensi dan berkomunikasi, mengkoordinasikan gerakan, berinteraksi dengan lingkungan, menumbuhkan rasa percaya diri, dan meningkatkan kemampuan akademis seperti membaca, menulis, menerima maupun mengekspresikan Bahasa (Nurcholis et al., 2018).

\section{Kemampuan Motorik Anak}

Kemampuan Motorik adalah kemampuan dalam mengkoordinasi gerakan tubuh. (Sutrisno et al., 2012), kecerdasan motorik adalah kemampuan seseorang untuk menggerakkan tubuhnya secara tepat. Ada saat harus lembut, pelan, dan ada saat harus keras dan cepat, serta kemampuan untuk menggerakkan tubuh sesuai yang diinginkan Perkembangan motorik merupakan proses tumbuh kembang kemampuan gerak seorang anak. Pada dasarnya, perkembangan ini berkembang sejalan dengan kematangan saraf dan otot anak. Sehingga, setiap gerakan sesederhana apapun merupakan hasil pola interaksi yang kompleks dari berbagai bagian dan sistem dalam tubuh yang dikontrol oleh otak. Kemampuan motorik terbagi dua yaitu motorik kasar dan motorik halus.

Perkembangan motorik adalah proses sejalan dengan bertambahnya usia secara bertahap dan berkesinambungan gerakan individu meningkat dari keadaan sederhana, tidak terorganisasi, tidak terampil ke arah penampilan keterampilan motorik yang kompleks dan terorganisasi dengan baik, yang pada akhirnya ke arah penyesuaian keterampilan (Busthomi, 2012).

Lebih lanjut (Firdani, 2009) dalam bukunya Inspiring Education PAUD mengemukakan bahwa, perkembangan motorik sangat dipengaruhi oleh organ otak dan kematangan syaraf. Otaklah yang mengendalikan setiap gerakan yang dilakukan oleh anak. Semakin matangnya perkembangan sistem syaraf otak yang mengatur otot, memungkinkan berkembangnya kompetensi atau kemampuan motorik anak.

Ada dua macam kemampuan motorik anak yaitu kemampuan motorik kasar dan motorik halus. Kemampuan motorik halus pada anak usia dini adalah beraktivitas dengan menggunakan otot halus seperti menulis, meremas, menggenggam, menggambar, menyusun balok dan memasukkan kelereng ke dalam lubang, sedangkan motorik kasar anak adalah kemampuan menggerakkan berbagai bagian tubuh seperti berjalan, melompat, berlari, melempar, menangkap, menendang, dan bermain sepeda (Abdurrahman, 2003).

\section{Anak Autis}

Autisme dalam (Griggs, 2012) didefinisikan sebagai gangguan perkembangan dengan tiga trias gangguan perkembangan yaitu gangguan pada interaksi sosial, gangguan pada komunikasi dan keterbatasan minat serta kemampuan imajinasi. Kata autisme sendiri berasal dari bahasa latin yaitu autos yang artinya sendiri (menyendiri). Penyandang autisme seakan hidup dalam dunianya sendiri. Istilah Autisme baru diperkenalkan sejak tahun 1943 oleh Leo Kanner. Istilah yang lazim dipakai saat ini oleh para ahli adalah kelainan spektrum autistik atau ASD (Autistic Spectrum Disorder). (Aguirre, 2014).

Sementara itu, Berk dalam (Yuwono, 2009) mengartikan autisme dengan istilah absorbed in the self atau keasyikan dalam dirinya sendiri. Wall mengartikan autisme sebagai aloof atau withdrawl, yang mana anakanak dengan gangguan autisme ini tidak tertarik dengan dunia di sekelilingnya. Kemudian, Tilton mengungkapkan bahwa pemberian nama autisme karena hal ini diyakini dari keasyikan yang berlebihan dalam dirinya sendiri.

Selanjutnya (Maulana, 2007) menjelaskan bahwa anak autistik mengalami gangguan perkembangan yang kompleks sehingga mereka juga disebut mengalami gangguan pervasif. Istilah pervasif juga dilandasi oleh gangguan perkembangan yang diperlihatkan oleh anak autis. Gangguan-gangguan itu hampir meliputi seluruh aspek kehidupannya, antara lain komunikasi, interaksi sosial, gangguan dalam sensoris, pola bermain, perilaku khas, dan emosi.

Penjelasan lebih lanjut dalam (Delphie, 2009), mengenai perilaku yang sering tampak pada anak dengan sindrom autistik, antara lain apabila dipanggil namanya ia tidak pernah menyahut, tidak mau mendengarkan orang berbicara dengannya, ekspresi wajahnya terlihat datar, tidak menatap wajah seseorang secara langsung, menarik tangannya jika ada yang menyentuh tangannya, serta tanpa permisi saat melewati orang yang duduk. Bahkan kadang-kadang ia meloncati orang yang sedang duduk. Perilaku lain yang ditunjukkan adalah tidak pernah menunjukkan rasa simpati terhadap orang lain yang kesakitan atau kesusahan.

Autisme terjadi 5 dari setiap 10.000 kelahiran dengan jumlah penderita laki-laki empat kali lebih besar dibandingkan dengan penderita perempuan. (Maulana, 2007). Namun demikian, jika perempuan yang menderitanya, umumnya akan lebih parah dibandingkan dengan laki-laki. (Yuwono, 2009) menambahkan 
bahwa gangguan autisme sendiri pada anak ditandai dengan tiga gangguan utama. Pertama, gangguan interaksi sosial. Kedua, gangguan komunikasi. Ketiga, gangguan perilaku. Jika interaksi sosial pada anak gangguan autisme ini membaik, maka gangguan komunikasi dan perilaku akan membaik juga .

\section{Metode}

Penelitian ini merupakan penelitian lapangan (field research), dengan deskripsi data kualitatif. Teknik pengumpulan datanya melalui wawancara mendalam, observasi partisipatif, serta dokumentasi. Sumber informasi (informan) dalam wawancara ini adalah Koordinator Pelayanan PLA, Koordinator Terapis, Terapis Sensori Integrasi (SI), Orangtua Anak Autis, dan Staf Tata Usaha (TU). Adapun anak autis yang menjadi subjek dalam penelitian ini berjumlah 5 anak, antara lain: RH (laki-laki, 4 tahun), JHA (perempuan, 3 tahun), ASP (laki-laki, 8 tahun), NCD (laki-laki, 10 tahun) dan terakhir AR (laki-laki, 6 tahun).

\section{Hasil dan Pembahasan}

1. Implementasi Latihan Sensorimotorik dalam Pengembangan Kinestetik Anak Autis di PLA

a. Prinsip Pelaksanaan Latihan Sensori-motorik

Berdasarkan hasil observasi dan wawancara dengan terapis, maka ditemukan beberapa prinsip pelaksanaan latihan sensori-motorik di Pusat Layanan Autis Provinsi Kepulauan Bangka Belitung, antara lain:

1) Kesempatan yang sama (equality of oppurtunity) berlaku juga bagi anak autis dan anak berkebutuhan khusus dalam memperoleh layanan pengembangan diri. Sebagaimana pada anak lainnya seperti mendapatkan pendidikan yang layak, bermain bersama, mendapatkan kasih sayang.

2) Perbedaan dan keunikan. Setiap Anak autis dan anak berkebutuhan khusus memiliki keunikan tersendiri sehingga berbeda dengan anak lainnya, bahkan anak yang menderita autis juga. Oleh karena itu, perlu diperhatikan perbedaan dan keunikan ini agar tidak salah dalam memberikan penanganan dan memenuhi kebutuhan masing-masing anak autis.

3) Waktu yang panjang. Gangguan spektrum autisme merupakan sebuah gangguan proses perkembangan, karena itu terapi jenis apapun yang dilakukan dan diberikan akan memerlukan waktu yang tidak sebentar namun dalam waktu yang lama. Terapi penanganan anak autis harus dilakukan dengan cara terpadu dan setiap penyandang gangguan ini membutuhkan jenis terapi yang berbeda sesuai kondisinya.

4) Perlu diingat bahwa tujuan utama dalam menangani anak autis dan anak berkebutuhan khusus yaitu mendorong kemandirian mereka, jika memungkinkan bisa juga mengembangkan bidang peningkatan akademiknya.

5) Orangtua dan guru-guru sekolah, serta orang yang memberikan terapi lainnya harus bekerja sama, saling bersikap terbuka, serta selalu berkomunikasi untuk membuat daftar perencanaan penanganan dengan teknik yang terbaik bagi anak-anak mereka.

6) Pengajaran yang terstruktur sangat penting. Sehingga, materi yang diberikan haruslah direncanakan sebaik mungkin dan bersifat kontinu.

7) Terapi yang dilaksanakan bersifat individual, jadi satu terapis menangani satu anak sesuai dengan jadwal yang ditentukan (one on one).

b. Acuan Pengembangan

Durasi waktu, asesmen, dan evaluasi program menjadi acuan dalam pengembangan latihan sensori-motorik di PLA. Berdasarkan penjelasan dari terapis di PLA, untuk mengetahui terapi apa yang dibutuhkan anak, maka harus melewati proses asesmen terdahulu. Kemudian tahap berikutnya adalah tahap observasi selama satu bulan. Bertujuan untuk mengetahui karakteristik perkembangan anak serta acuan untuk menyusun program latihan sensori motorik yang dikenal dengan matrix planning. Program yang tersusun tersebut akan menjadi pedoman dalam proses latihan yang dilaksanakan sebanyak dua kali pertemuan dalam seminggu. Sekali pertemuan menghabiskan waktu selama 1 jam.

Latihan sensori motorik yang diberikan menyesuaikan dengan karakteristik kebutuhan anak, karena anak yang satu dengan anak yang lainnya mempunyai kondisi yang berbeda. Program latihan tersebut dibuat berdasarkan hasil observasi selama 1 bulan. Setelah masa observasi tersebut maka anak masuk ke tahap terapi 1 selama 3 bulan, setelah selesai dilanjutkan dengan terapi tahap 2 selama 3 bulan juga. Penyusunan program terapi tahap 2 berdasarkan hasil evaluasi perkembangan anak pada tahap 1. Jika ada latihan anak yang belum bagus di tahap 1 maka diulang lagi pada tahap 2, jika 
latihan di tahap 1 sudah bagus, maka tidak perlu diulang lagi pada tahap 2 karena dilanjutkan dengan latihan yang lain.

Perkembangan sensori motorik anak dalam terapi sensori integrasi dilakukan evaluasi oleh terapis berdasarkan proses terapi selama 3 bulan. Setiap kali pertemuan terapis juga menyampaikan aktivitas latihan dan perkembangan anak kepada orangtuanya melalui buku penghubung dan obrolan santai ketika ada waktu senggang tertentu. Selain itu, evaluasi bisa juga didukung oleh catatan orangtua tentang aktivitas anak selama di rumah, biasanya dari kegiatan anak sejak bangun tidur sampai malam termasuk makanan yang dikonsumsi oleh anak di rumah, karena makanan akan mempengaruhi tingkat keaktifan anak selama latihan.

c. Penerapan Latihan Sensori Motorik

Latihan dalam program terapi sensori integrasi terdiri dari 7 bidang pengembangan, antara lain: vestibular (berhubungan dengan keseimbangan koordinasi tubuh), taktil (latihan untuk menstimuluskan indera perasa atau sentuhan), propioseptik (berhubungan dengan latihan untuk menstabilkan otot/persendian), visual (latihan mengoptimalkan indera penglihatan), auditori (latihan yang berhubungan dengan indera pendengaran), gustatori (latihan untuk menstimulus kepekaan indera pengecap), dan olfaktori (latihan yang bertujuan untuk mengoptimalkan kepekaan indera penciuman). Latihan yang diberikan sesuai dengan tingkat kebutuhan anak, karena kondisi dari masing-masing mereka berbeda. Aplikasi latihan tersebut contohnya seperti gambar-gambar berikut ini:

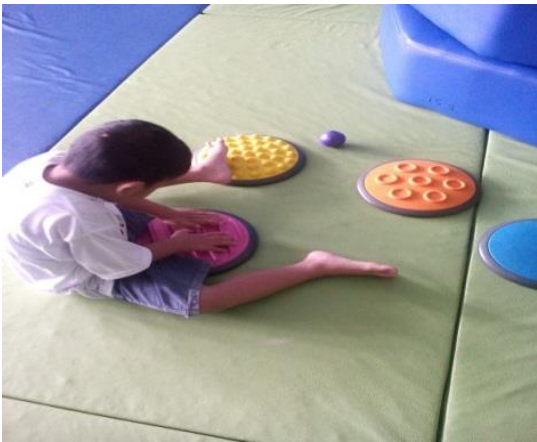

Gambar.1. Menggosok tekstur kasar-halus

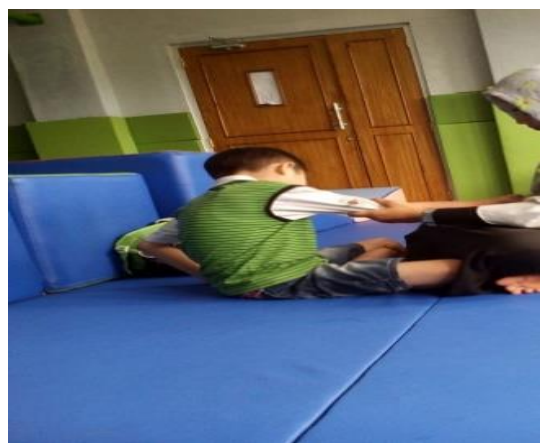

Gambar.3. Meremas sendi

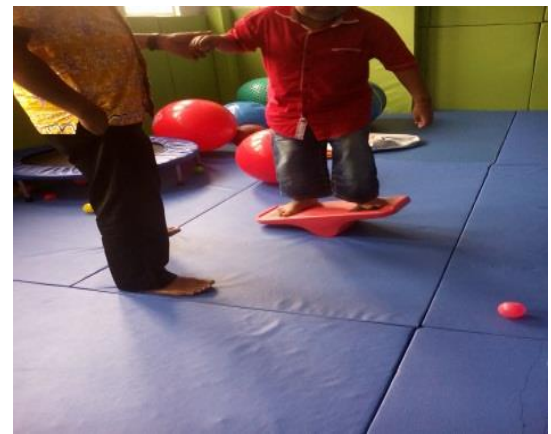

Gambar.2. Latihan keseimbangan

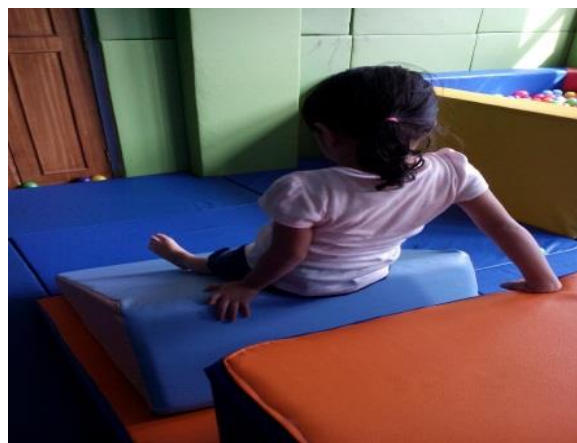

Gambar.4. Latihan perosotan/meluncur

2. Kemampuan Motorik Anak Autis di Pusat Layanan Autis (PLA) Provinsi Kepulauan Bangka Belitung Anak yang diidentifikasi sebagai autis kemampuan geraknya kurang dibanding dengan anak normal sebayanya, diukur dari kemampuan gerak statis dan dinamis, kekuatan, koordinasi, keseimbangan dan kelincahan. Kemampuan motorik anak autis tidak seperti anak pada umumnya. Kondisi perkembangan mental yang tertinggal, berdampak pada kemampuan motorik anak autis. Hal ini disebabkan adanya gangguan pada sistem syaraf pusat. Oleh karena itu, anak autisme pada umumnya memiliki kecakapan motorik yang lebih rendah dibandingkan dengan kelompok anak sebayanya, baik secara kualitatif maupun kuantitatif (Delphie, 2009). 
Berdasarkan hasil observasi dan wawancara dengan terapis, adapun karakteristik gangguan sensori motorik dari kelima subjek sebelum menjalankan terapi sensori integrasi di Pusat Layanan Autis Provinsi Kepulauan Bangka Belitung, yaitu sebagai berikut:

a. RH: jenis kelamin laki-laki berusia 4 tahun, karakteristik disfungsi sensori motoriknya tergolong hipoaktif yaitu gerakan badan lemas, tidak banyak gerak. Mempunyai kelemahan postur saat berdiri atau duduk, memegang benda terlalu longgar, sangat mudah kelelahan. Mempunyai keseimbangan yang rendah, mempunyai ketakutan bermain ayunan. Hipersensitif yaitu tidak suka disentuh atau dipegang. Terapi yang diberikan, terapi sensori integrasi (SI) dan terapi perilaku. Tujuan didampingi dengan terapi perilaku untuk meningkatkan kepatuhan $\mathrm{RH}$, sehingga $\mathrm{RH}$ mampu melakukan aktivitas, menirukan gerakan motorik kasar, motorik halus dan imitasi terhadap objek.

b. JHA: jenis kelamin perempuan, berusia 3 tahun. Karakteristik JHA ketika menjalankan latihan yaitu suka tantrum. Kemarahan yang terjadi diekspresikan ke dalam perilaku menangis, melempar-lempar mainan, agresif terhadap diri sendiri yaitu suka menggigit kuku, mengeraskan badan tidak mau ikut kegiatan. Sensori integrasi tergolong hipersensitif yang ditandai dengan tidak suka disentuh, geli berlebihan dengan bola plastik kecil yang bila dimasukkan di bak bola ia muntah-muntah serta menangis, begitupun jika didekatkan dengan bola tersebut, maka ia pergi dan bergumam. Keseimbangan badan rendah seperti kesulitan naik turun tangga, hipoaktif, memegang benda terlalu kuat. Terapi yang diberikan adalah SI dan perilaku.

c. NCD: jenis kelamin laki-laki berusia 10 tahun, Kontak mata NCD tidak fokus atau cuek, maka perhatian teralihkan. Ketika diajak berbicara atau mengikuti kegiatan, pandangan tidak tertuju sehingga terapis harus mengingatkan dan memegang kepalanya untuk diarahkan pandangannya. Munculnya kekakuan dan kekerasan otot, postur lemah saat berdiri atau duduk, gangguan verbal tergolong berat. Terapi yang diberikan yaitu terapi SI, terapi perilaku, dan terapi wicara (di rumah).

d. AR: jenis kelamin laki-laki, berusia 6 tahun. Gerakan tidak terkontrol seperti sering lari-lari, sering kesandung serta nabrak benda di ruangan, suka memanjat sesuatu yang tinggi seperti meja, kulkas, dan lemari. Tatapan mata tidak fokus, gerakan badan kaku, sering terpukau dengan benda-benda yang berputar. Gangguan verbal tergolong berat, tidak merespons jika dipanggil atau diperintahkan, jika mengekspresikan kemauannya hanya dengan menangis. Jenis terapi yang tengah diberikan adalah terapi SI dan terapi wicara. Sebelumnya juga sudah menjalani terapi perilaku.

e. ASP: jenis kelamin laki-laki, berusia 8 tahun. Kebetulan anak ini tergolong gemuk jadi berpengaruh terhadap keseimbangan badannya dalam bergerak. Ia kesulitan dalam naik-turun tangga, melompat, meloncat, mudah kelelahan. Sehingga ASP termasuk hipoaktif dalam aktivitas gerak. Perilakunya suka tantrum, menyakiti diri sendiri (menggigit tangan), kurang respons terhadap perintah. Namun, mempunyai ketajaman visual serta keterampilan motorik halus yang bagus, terbukti dari ia pandai menggambar tanpa melihat objek langsung, hasil coretan tangan yang rapi, dan tulisan huruf yang bagus juga. Terapi yang diberikan adalah terapi SI, okupasi, dan bina diri.

Berdasarkan evaluasi dari hasil observasi peneliti, bahwa kegiatan sensori motorik dari kelima subjek, semuanya mempunyai karakteristik kemampuan yang berbeda-beda. RH, JHA dan ASP lebih bagus perkembangannya dibanding NCD dan AR. Umur juga berpengaruh terhadap kemajuan atau kecepatan dalam merespons stimulasi latihan. JHA dan RH tergolong usia Balita. NCD menjelang 10 tahun. AR 6 tahun, dan ASP 8 tahun.

Selanjutnya dari hasil wawancara dengan ibu MSA selaku terapis, bahwa NCD sangat lambat merespons stimulasi latihan, gerakan otot dan badannya sangat kaku, maka dari itu butuh latihan yang sangat ekstra dibanding usia di bawahnya. Sebaiknya, jika sudah mengetahui ada gangguan atau hambatan perkembangan motorik anak sejak dini, sebagai orangtua maka segera ditangani, jangan dibiarkan berlarut, karena dengan semakin bertambahnya umur tingkat kematangan syaraf otot anak juga bertambah. Oleh sebab itu, ketika ada gangguan semacam ini bisa lebih sulit untuk ditangani.

Stimulasi lingkungan, dan latihan yang dilakukan di rumah juga berpengaruh terhadap kemajuan perkembangan motorik anak autis, selain fakor umur anak tersebut. Berdasarkan hasil wawancara dengan terapis dan orangtua, bahwa JHA, RH, dan ASP, selama di rumah mereka rajin dilatih oleh orangtua mereka. Pekerjaan rumah (PR) yang diberikan oleh terapis di Pusat layanan Autis, disiplin orangtua terapkan walaupun dengan media seadanya.

Kemudian subjek AR, berdasarkan penuturan ibu dan bapaknya, selama di rumah PR dari terapis tidak sepenuhnya dijalankan. Dengan alasan karena AR sering tidak mau, dan orangtua AR susah membujuk sebab merasa tidak tega, jadi latihannya tergantung kemauan AR saja. Sedangkan NCD menurut keterangan dari terapis yang menanganinya bahwa, Program latihan yang dijalankan di rumah juga kurang maksimal, NCD sehabis terapi biasanya dibawa ke tempat orangtuanya kerja, sementara ruangnya sempit, 
jadi otomatis ruang gerak NCD pun terbatas. NCD termasuk kurang adaptif terhadap lingkungan, ketika namanya dipanggil sering tidak merespons.

AR ketika awal-awal terapi mempunyai gerakan yang tidak terkendali, ia sering lari-lari di ruangan dan kesandung. Tingkat kepatuhan sangat rendah, ia juga suka memanjat sesuatu yang tinggi dalam ruangan. Ketika sudah sering diberikan terapi gerakan AR lebih terkontrol dari sebelumnya, hiperaktif menurun, sudah menunjukkan sikap kepatuhan, sudah berhenti memanjat barang yang tinggi di ruangan.

Ketika awal-awal terapi, RH sama sekali tidak mau masuk ruangan, sering mengamuk, tidak mau mengikuti arahan terapis. Setelah terapi berjalan lama, RH mulai menikmati suasana ruangan, sudah mau diarahkan, mulai beradaptasi, sehingga perkembangan motoriknya mulai meningkat.

Setelah sering mengikuti latihan di terapi sensori integrasi, JHA menunjukkan perkembangan yang lebih baik seperti hipersensitif yang berkurang, lebih bisa berdaptasi dengan lingkungan terapi, ketika dimasukkan di bak bola tidak muntah lagi, hanya ia bergegas menjauh. Keadaan sebelumnya atau awal-awal terapi, JHA mempunyai hipersensitif yang tinggi, sering muntah-muntah jika dimasukkan di bak bola, sering mengamuk serta menangis, susah dibujuk ke ruangan terapi.

3. Kendala dalam Latihan Sensorimotorik

Berikut ini ada beberapa faktor penghambat dalam melaksanakan intervensi latihan sensori motorik anak autis, antara lain:

a. Asupan nutrisi yang tidak disiplin

Anak dengan autisme memiliki kebutuhan khusus dalam beberapa hal. Tak hanya masalah pola asuh, tetapi juga pola makannya yang juga berpengaruh terhadap perilaku. dibutuhkan gizi seimbang dan nutrisi yang baik bagi perkembangan otaknya. Anak autis perlu banyak mengkonsumsi makanan yang mengandung omega 3 dan mineral. Namun, tidak semua makanan dapat diberikan kepada mereka karena ada beberapa pantangan makanan yang sebaiknya tidak dikonsumsi.

b. Orangtua tidak konsisten menjalankan PR di rumah yang diberikan oleh terapis Pusat Layanan Autis, yaitu PR berupa melatih kinestetik anak dengan aktivitas tertentu.

Pengasuhan anak adalah bagian dari proses sosialisasi tata pergaulan keluarga yang mengarah pada terciptanya kondisi kemandirian anak. Pola asuh orang tua ini sangat mempengaruhi bagaimana anak berperilaku.

4. Optimalisasi Latihan Sensori Motorik

Faktor-faktor yang mendukung latihan sensori motorik di Pusat Layanan Autis Provinsi Kepulauan Bangka Belitung, antara lain:

a. Prasarana yang menunjang

Fasilitas atau sarana prasarana di pusat layanan autis bangka Belitung, menurut pendapat beberapa terapis dan orangtua sudah memadai. Fasilitas yang ada masih bagus dan sesuai kebutuhan anak. Fasilitas di ruang sensori integrasi tercukupi untuk melakukan aktifitas latihan sensori motorik.

b. Kerjasama/komunikasi yang lancar antar terapis

Pengurus Pusat Layanan Autis atau para terapis sering mengadakan briefing baik sebelum melaksanakan kegiatan maupun ketika selesai kegiatan, termasuk dalam obrolan santai. Komunikasi yang lancar ini sangat membantu dalam memberikan masukan satu sama lain demi kepentingan perkembangan anak, karena perkembangan kemampuan anak dalam terapi tertentu juga berpengaruh terhadap terapi lain yang dijalani anak.

c. Sikap Penerimaan orangtua/keluarga

Orangtua yang menerima kondisi anaknya, bisa mempermudah interaksi atau komunikasi dengan pihak Pusat Layanan Autis. Karena peran orangtua memegang peran yang besar terhadap perkembangan anaknya, termasuk informasi kegiatan anaknya selama di rumah.

d. Program yang dinamis

Program pengembangan latihan sensori motorik dibuat secara berkesinambungan dan sesuai tingkat kebutuhan anak, selain itu evaluasi juga dilakukan para terapis secara otentik demi kelancaran kegiatan berikutnya

\section{Kesimpulan}

Gangguan sensori berbeda-beda antara satu anak dengan anak lainnya, baik dari segi intensitas maupun kriterianya. Gangguan tersebut berupa hipersensitif atau hiposensitif. Contoh hipersensitif seperti kesulitan untuk mentolerir cahaya di kamar, tidak suka disentuh (terutama sentuhan ringan) dan kegelisahan ketika melihat langsung mata orang lain (menghindari kontak mata). Hiposensitif, ciri-cirinya adalah toleransi 
yang luar biasa tinggi terhadap stimulasi lingkungan. Ketika mencari stimulasi sensori anak dengan hiposensitif akan terlihat gelisah.

Autisme merupakan gangguan neurobiologis yang menetap. Gejala autisme tampak pada gangguan bidang interaksi sosial, komunikasi, dan perilaku. Meskipun gangguan neurobiologis tidak dapat diobati, gejala-gejalanya dapat dihilangkan atau dikurangi, sampai orang awam kemudian tidak dapat lagi membedakan mana anak dengan gangguan autisme dengan anak non-autisme.

Anak autis memiliki kekurangan dalam kemampuan mengolah, mengartikan seluruh rangsangan sensoris yang diterima oleh tubuh maupun lingkungan dan menghasilkan respons yang terarah. Terapi integrasi sosial ini berfungsi meningkatkan kematangan susunan saraf pusat. Aktivitas terapi ini merangsang koneksi sinaptik yang lebih kompleks sehingga dapat meningkatkan kapasitas kemandirian dalam belajar.

\section{Referensi}

Abdurrahman, M. (2012). Anak Berkesulitan Belajar. In Anak Berkesulitan Belajar.

Aguirre, B., \& Sastry, A. (2014). Parenting Anak dengan Autisme: Solusi, Strategi, dan Saran Praktis untuk Membantu Keluarga Anda. Yogyakarta: Pustaka Belajar.

Ahmad Susanto. (2011). Perkembangan anak usia dini. In Jurnal Golden Age Hamzanwadi University.

Arifin, Z. (2012). Penelitian Pendidikan; Metode dan Paradigma Baru. Bandung: PT Remaja Rosdakarya.

Busthomi, M. Y. (2012). Panduan Lengkap PAUD: Melejitkan Potensi dan Kecerdasan Anak Usia Dini. Perpustakaan Nasional: Citra Publishing.

Crain, W. (2014). Teori Perkembangan Konsep dan Aplikasi: Edisi Ketiga, terj. Yudi Santoso. Yogyakarta: Pustaka Belajar.

Delphie, B. (2009). Pendidikan Anak Autistik. Yogyakarta: PT Intan Sejati Klaten.

Firdani, L. (2009). Inspiring Education PAUD, Jakarta: Kompas Gramedia.

Griggs, J. (2012). Parenting Your Child With Autism: Practical Solutions, Strategies, and Advice for Helping Your Family. Consumer Connections.

Kementerian Pendidikan Nasional. (2003). UU Nomor 20 Tahun 2003 tentang Sistem Pendidikan Nasional. In Undang-Undang Republik Indonesia Nomor 20 Tahun 2003 Tentang Sistem Pendidikan Nasional Dengan Rahmat Tuhan Yang Maha Esa Presiden Republik Indonesia.

Marienzi, R. (2012). Meningkatkan kemampuan mengenal konsep angka melalui metode multisensori bagi anak autis. E-Jupekhu (Jurnal Ilmiah Pendidikan Khusus).

Maulana, M. (2007). Anak Autis: Mendidik Anak Autis dan Gangguan Mental Lain Menuju Anak Cerdas dan Sehat. Yogyakarta: Ar-Ruzz Media.

Mudjito. (2014). Deteksi Dini, Diagnosa Gangguan Spectrum Autisme dan Penanganan dalam Keluarga. Jakarta: Kementerian Pendidikan dan Kebudayaan.

Mudjito, Elfindri, Harizal, \& Rezki, J. F. (2014). SCHOOLS AND THE DISABILITY: A CASE OF INDONESIAN CHILDREN. SOCIOINT14: International Conference on Social Sciences and Humanities.

Musbikin, I. (2012). Pintar Mengatasi Masalah Tumbuh Kembang Anak. Jogjakarta: FlashBooks.

Nurcholis, D., Soedjarwo, S., \& Mudjito, M. (2018). Transformation of Multicultural Education Management in Primary School. https://doi.org/10.2991/icei-18.2018.25

Peraturan Pemerintah. (2010). PERATURAN PEMERINTAH REPUBLIK INDONESIA NOMOR 71 TAHUN 2010 TENTANG STANDAR AKUNTANSI PEMERINTAHAN. $P p$. https://doi.org/10.1093/occmed/kqq062

Picauly, V. E. (2016). BELAJAR DAN PEMBELAJARAN BERDASARKAN TEORI PSIKOLOGI BELAJAR BEHAVIORISTIK. JURNAL PENDIDIKAN ILMU SOSIAL.

https://doi.org/10.17509/jpis.v22i1.2200 
Prasetyoningsih, L. S. A. (2016). PENGEMBANGAN TINDAK BAHASA TERAPI DALAM INTERVENSI ANAK AUTIS SPEKTRUM PERILAKU. LITERA. https://doi.org/10.21831/ltr.v15i1.9771

Resmisari, R. (2016). Penerapan Metode ABA ( Applied Behavior Analysis ) untuk Meningkatkan Kontak Mata pada Anak dengan Gangguan Autis : Sebuah Laporan Kasus. 2nd Psycology \& Humanity.

Susanto, A. (2011). Perkembangan Anak Usia Dini: Pengantar dalam Berbagai Aspeknya. Jakarta: Kencana.

Sutrisno, J., Zulkarnaen, \& Noh, M. M. (2012). Peran Dinas Pendidikan, Pemuda dan Olahraga dalam Meningkatkan Prestasi Olahraga di Kabupaten Pontianak. Tesis PMIS-UNTAN-IAN 2012. 